[3] Colaianni G, Cuscito C, Mongelli T, et al. Irisin enhances osteoblast differentiation in vitro. Int J Endocrinol 2014;2014:902186.

[4] Sivordova LE, Zavodovsky BV, Polyakova JV, et al. Adiponectin as a useful marker for diagnosis of osteoporosis in rheumatoid arthritis patients. Osteoporosis Int. 2016;27(S.1):135.

Disclosure of Interest: None declared DOI: 10.1136/annrheumdis-2018-eular.4463

\section{AB0058 IL2 DECREASE AND INCREASE OF IL10 AND INF1A ARE ASSOCIATED TO CLINICAL ACTIVITY IN SYSTEMIC LUPUS ERYTHEMATOUSPATIENTS}

E. Grau ${ }^{1}$, C. Feced ${ }^{1}$, E. Labrador ${ }^{1}$, F.M. Ortiz ${ }^{1}$, C. Alcañiz ${ }^{1}$, K. Arevalo $^{1}$, I. Chalmeta ${ }^{1}$, M. De la Rubia ${ }^{1}$, J. Fragio ${ }^{1}$, R. Gonzalez ${ }^{1}$, L. Gonzalez ${ }^{1}$, J. Ivorra ${ }^{1}$, I. Martinez ${ }^{1}$, R. Negueroles ${ }^{1}$, J. Oller ${ }^{1}$, E. Vicens ${ }^{1}$, C. Najera', I. Canovas ${ }^{1}$, D. Hervas ${ }^{2}$, M. Fernandez ${ }^{3}$, N. Fernandez-Llanio ${ }^{3}$, J.A. Castellano ${ }^{3}$, F. Mayo ${ }^{4}$, J. A. Roman ${ }^{1} .{ }^{1}$ Rheumatology Department, HUP La Fe; ${ }^{2}$ Biostatistical Unit, IIS La Fe; ${ }^{3}$ Rheumatology Section, H. Arnau de Vilanova; ${ }^{4}$ Medical School, UCV, Valencia, Spain

Background: Systemic lupus erythematous (SLE) is an autoimmune disease characterised by deregulation of cytokine production. INF1A is a proinflamatory cytokine considered as a key molecule in the SLE etiopathogenesis, being responsible indirectly of IL10 upregulation. BLyS is involved in autoantibodies production and clinical activity in SLE, and its expression is regulated by other cytokines as IL10 and INF1A. IL2 is an anti-inflammatory cytokine in SLE, but its loss leads to the production of Th2 proinflammatory cytokines as IL4, IL5 and IL13.

Objectives: To analyse the association among inflammatory cytokine levels and clinical activity, as well as to identify a cytokine profile related to disease activity in SLE.

Methods: A cross-sectional, observational study of 142 patients diagnosed of SLE SLICC 2012 criteria), and 35 healthy controls, was performed. A complete blood-test and an interview were carried out to collect their clinical data. We analysed inflammatory cytokines serum levels by colorimetric methods. Biostatistical analysis with $\mathrm{R}$ was performed.

Results: Mean cytokine levels for the SLE patients and healthy controls are shown in the table 1.

Abstract AB0058 - Table 1

\begin{tabular}{lcc}
\hline & $\begin{array}{c}\text { SLE patients }(\mathrm{pg} / \\
\mathrm{mL})\end{array}$ & $\begin{array}{c}\text { Healthy controls }(\mathrm{pg} / \\
\mathrm{mL})\end{array}$ \\
& Mean (SD) & Mean (SD) \\
\hline IL2 & $4.34(12.2)$ & $4,96^{4,5}$ \\
IL4 & $58.65(64.6)$ & $89,05^{70,18}$ \\
IL5 & $18(5.71)$ & $7,33^{8,59}$ \\
IL10 & $12.29(32.82)$ & $1,92^{3,67}$ \\
IL13 & $44.97(273.78)$ & $42,85^{93,05}$ \\
IL21 & $3.18(5.61)$ & $2,82^{3,35}$ \\
INF1A & $15.69(24.59)$ & $4,84^{1,91}$ \\
BLyS & $2293.82(6948.46)$ & $1181,15^{260,04}$ \\
\hline
\end{tabular}

The mean clinical activity measured by SLEDAI was $5.91 \pm 5.06$, and we observed a statistically significant association between high levels of IL10 and high clinical activity $(p=0.001)$.

Statistical analysis indicates that complement consumption is associated with increased levels of IL10 ( $p=0.029)$, INF1A ( $p<0.001)$, IL4 ( $p=0.004)$, IL5 ( $p=0.009)$ and decreased levels of IL2 ( $\mathrm{p}=0.045)$; or anti-DNA positivity is associated with increased levels of INF1A $(p=0.002)$ and decreased levels of IL2 $(p=0.045)$, IL4 $(\mathrm{p}=0.034)$ and IL5 $(\mathrm{p}=0.007)$.

Moreover, BLyS seems to have increased in patients with positive antiphospholipid antibodies and anti-DNA. IL10 is associated with ENAs positivity $(p=0.022)$. In patients with other autoimmune disease associated with SLE, an increase of INF1A $(p=0.008)$ and IL5 $(p=0.044)$ is observed.

SLE patients were categorised by normal, low or high level of the eight citokines. Despite the fact that no specific cytokine profile associated with clinical activity was observed, those patients with high SLEDAI score had increased levels of IL10 and INF1A and decreased levels of IL2 and IL21.

Conclusions: Our SLE patients displayed mainly IL10, INF1A and BLyS increased, and IL2 decreased. Although IL10 seems to be the cytokine which best fits to clinical activity in SLE, altered levels of INF1A, IL2, IL4, and IL5 are associated with complement consumption or anti-DNA positivity.

Disclosure of Interest: None declared

DOI: 10.1136/annrheumdis-2018-eular.6747

\section{$\mathrm{AB} 0059$ \\ FETUIN-A: CLINICAL AND LABORATORY ASSOCIATIONS IN WOMEN WITH RHEUMATOID ARTHRITIS}

E. Papichev ${ }^{1}$, L. Sivordova ${ }^{1}$, J. Polyakova ${ }^{1}$, Y. Akhverdyan ${ }^{1}$, B. Zavodovsky ${ }^{1}$, T. Rogatkina ${ }^{2} .{ }^{1}$ Treatment and Prevention of Joint Disease Laboratory, Federal State Budgetary Institution «Research Institute of Clinical and Experimental Rheumatology named after A.B. Zborovsky»; ${ }^{2}$ Volgograd State Medical University, Volgograd, Russian Federation

Background : Fetuin- $A$ is an acute-phase protein with contradictory effects. It is well known that fetuin- $A$ low levels are associated with calcification and higher risk of cardiovascular diseases and its level is downregulated by pro-inflammatory cytokines. ${ }^{1}$ Nevertheles, it was shown, that fetuin-A induces synthesis of proinflammatory cytokines in adipocites and macrophages. ${ }^{2}$

Objectives: To investigate the level of fetuin- $A$ in women with rheumatoid arthritis (RA).

Methods: At baseline we measured fetuin-A level, femoral neck, total hip and $L_{1}$ $L_{\text {IV }} B M D$ by DXA in 110 women with $R A$ (mean age $54,5 \pm 12,6$; hereinafter $M \pm S t d$. dev.) and 30 healthy controls. Serum CRP and ESR were measured to assess inflammation. DAS28 was calculated to determine RA activity. The diagnosis of osteoporosis was set according to the recommendations of world health organisation - T-score $\leq-2,5$ for patients without glucocorticoid therapy in anamnesis, Tscore $\leq-1,5$ for patients treated with glucocorticoid for 3 months in anamnesis or with an osteoporotic fracture in anamnesis. Fetuin-A in serum was determined by enzyme-linked immunosorbent assay.

Results: Mean concentration of fetuin-A in group with RA was 765,69 $\pm 120,64 \mathrm{ug} / \mathrm{ml}$, which was lower than of healthy controls $-812,95 \mathrm{ug} / \mathrm{m}$ $(p=0,0438)$. Secondary osteoporosis was revealed in 52 patients $(47 \%)$ with RA with mean level of fetuin-A at $733,7 \pm 18,83 \mathrm{ug} / \mathrm{ml}$ vs. $794,36 \pm 12,83 \mathrm{ug} / \mathrm{m}$ $(p=0,0078)$ of $58(53 \%)$ non-osteoporotic patients. Moderate negative correlations were observed between fetuin-A and DAS28 $(r=-0,4334 ; p<0,001)$, fetuin-A and CRP $(r=-0,3148 ; p<0,001)$, fetuin- $A$ and ESR $(p=-0,344 ; p<0,001)$. Mean concentrations of fetuin- $A$ were significantly different between the subgroups with moder ate $(3,2 \leq \mathrm{DAS} 28<5,1)$ and high disease activity $(5,1 \leq \mathrm{DAS} 28)$ of RA patients and healthy controls: $742,41 \pm 12,07 \mathrm{ug} / \mathrm{ml}$ vs. $812,95 \mathrm{ug} / \mathrm{ml}(\mathrm{p}=0,0021)$ and 663,9 $\pm 39,14 \mathrm{ug} / \mathrm{ml}$ vs. $812,95 \mathrm{ug} / \mathrm{ml}(\mathrm{p}<0,001)$.

Conclusions: Our study confirms that lower levels of fetuin- $A$ are associated with higher activity of RA and with the loss of bone mineral density.

\section{REFERENCES}

[1] Brylka L, et al. Calcif Tissue Int 2012;93(4):355-364

[2] Stefan N, et al. Diabetes 2008;57(10):2762-2767.

Disclosure of Interest: None declared

DOI: 10.1136/annrheumdis-2018-eular.2111

\section{AB0060 MECHANISMS OF ACTION OF CHONDROITIN SULFATE AND GLUCOSAMINE IN MUSCLE TISSUE: IN VITRO AND IN VIVO RESULTS. A NEW POTENTIAL TREATMENT FOR MUSCLE INJURIES?}

E. Montell ${ }^{1}$, P. Contreras-Muñoz ${ }^{2}$, A. Torrent ${ }^{1}$, M. de la Varga ${ }^{3}$, G. Rodas ${ }^{4}$ M. Marotta ${ }^{5}$. ${ }^{1}$ Pre-Clinical RandD Area, Bioibérica, S.A.U; ${ }^{2}$ Bioengineering Cell Therapy and Surgery in Congenital Malformations Laboratory, Vall D'Hebron Institute. Leitat Technological Center, ${ }^{3}$ Leitat Foundation, Leitat Technological Center, ${ }^{4}$ Leitat Technological Center, FC Barcelona Medical Services; ${ }^{5}$ Bioengineering Cell Therapy and Surgery in Congenital Malformations Laboratory, Vall D'Hebron Institute. Leitat Techonological Center, Barcelona, Spain

Background: Musculoskeletal injures are the most common cause for severe, chronic pain and physical disability affecting hundreds of millions of people around the world and represent a major concern also in sports medicine. A preclinical study evaluated the impact of chondroitin sulfate (CS) and glucosamine (GLU) combination (both compounds used in the treatment of osteoarthritis) on muscle healing and force recovery. Although the mechanisms of action of the combination $\mathrm{CS}+\mathrm{GLU}$ have been largely studied in articular tissue, its potential therapeutic effects for muscle healing remain still unknown.

Objectives: The aim of the present study is to elucidate the mechanisms of action responsible for this interesting benefit.

Methods: Human skeletal muscle biopsies were digested with Protease type XIV and the resulting tissue suspension were collected by centrifugation. The digested muscle pellet was then triturated to liberate the human satellite cells. Differentia centrifugations were used to enrich the cell fraction. Cell suspension was then transferred onto cell-culture dishes in Growth media (DMEM/M-199 medium (3:1) with $10 \%$ FBS, $10 \mu \mathrm{g} / \mathrm{ml}$ insulin, $2 \mathrm{mM}$ glutamine, $25 \mathrm{ng} / \mathrm{ml}$ fibroblast growth fac tor, and $10 \mathrm{ng} / \mathrm{ml}$ epidermal growth factor) and cells were expanded in a growing monolayer. The effect of CS+GLU treatment in primary human skeletal muscle 